\title{
Quality of life in aphasia: differences between fluent and non-fluent aphasic Augmentative and Alternative Communication users
}

\section{Qualidade de vida na afasia: diferenças entre afásicos fluentes e não fluentes usuários de Comunicação Suplementar e/ou Alternativa}

\author{
Mariana Mendes Bahia', Regina Yu Shon Chun ${ }^{1}$
}

\begin{abstract}
Purpose: To investigate and to compare quality of life (QOL) in fluent and non-fluent aphasics. Methods: This is a prospective, quantitative, and transversal study. We included 11 stroke patients with aphasia (five non-fluent aphasics augmentative and alternative communication users and six fluent aphasics). Data was gathered from the Stroke Specific Quality of Life Scale (SS-QOL), a structure interview, and The Modified Rankin Scale. Results: The non-fluent aphasics presented poorer Rankin and quality of life than the fluent aphasics. The major difference occurred in the fields of language and upper extremity function. The three most affected domains in non-fluent aphasics were language, social roles, and thinking, whereas in the fluent aphasics were personality, social roles, and thinking. All the subjects referred a worse quality of life after stroke. The domains of language and self-care were identified as the most affected after stroke. Conclusion: This study demonstrated that, in general, non-fluent aphasics have lower quality of life than fluent aphasics. However, this difference is not homogeneous among the several quality of life domains. Additionally, this research evidences a relationship between aphasia severity and individual functionality, implying impairment in quality of life, especially for non-fluent aphasics.
\end{abstract}

Keywords: Aphasia; Quality of life; Stroke; Communication aids for disabled; Language

\begin{abstract}
RESUMO
Objetivo: Investigar e comparar a qualidade de vida de afásicos fluentes e não fluentes. Métodos: Trata-se de pesquisa prospectiva, quantitativa, transversal, cuja amostra se constituiu de 11 sujeitos afásicos (5 não fluentes, usuários de comunicação suplementar e/ou alternativa e 6 fluentes, não usuários de comunicação suplementar e/ou alternativa. A coleta de dados foi realizada por meio da aplicação de um questionário específico de qualidade de vida, entrevista estruturada e aplicação da escala de Rankin modificada. Resultados: Na comparação dos grupos estudados, os afásicos não fluentes apresentaram escores de Rankin e de qualidade de vida menores do que os fluentes e as maiores diferenças referiram-se aos domínios de linguagem e função do membro superior. Os domínios mais prejudicados pelo acidente vascular cerebral foram linguagem, relações sociais e modo de pensar, para os afásicos não fluentes, e comportamento, relações sociais e modo de pensar, para os fluentes. Todos os sujeitos relataram que sua qualidade de vida piorou após o acidente vascular cerebral, sendo que linguagem e cuidados pessoais foram apontados como os aspectos que mais mudaram, após o episódio lesional. Conclusão: Os achados mostram relação entre gravidade da afasia e funcionalidade do indivíduo, indicando que, no geral, os afásicos não fluentes apresentam qualidade de vida pior do que os fluentes. As diferenças não são homogêneas nos diversos domínios de qualidade de vida.
\end{abstract}

Descritores: Afasia; Qualidade de vida; Acidente vascular cerebral; Auxiliares de comunicação para pessoas com deficiência; Linguagem

Research done in the Speech-Language Pathology and Audiology Course, Universidade Estadual de Campinas - UNICAMP - Campinas (SP), Brazil. (1) Speech-Language Pathology and Audiology Course, Universidade Estadual de Campinas - UNICAMP - São Paulo (SP), Brazil.

Conflict of interests: No

Authors' contribution: $M M B$ main researcher, study design, research schedule, literature review, data gathering and analysis, paper writing and submitting; RYSC supervisor, study design, research schedule, data analysis revision, paper correction, approval of the final version.

Correspondence address: Mariana Mendes Bahia. R. Conselheiro Paula Sousa, 707, Cidade Universitária, Campinas (SP), Brazil, CEP: 13083-080. E-mail: mariana_mbahia@yahoo.com.br

Received on: 12/14/2013; Accepted on: 7/29/2014 


\section{INTRODUCTION}

Many are the factors which can cause damage to the quality of life (QOL) of individuals. In this study, aphasia is the focus, with a view to contribute to expand the knowledge in this area, due to the scarcity of studies, mainly in the literature about Speech-Language Pathology, and also due to its importance in several aspects in the life of individuals, for example, the dependence on a caretaker for daily activities, the disruption of social relations, language impairment, psycho-affective changes, such as depression, isolation, among others ${ }^{(1-4)}$.

As for these aspects, it is worth remembering the notions of QOL in health issues, since it has been through various changes throughout the last decades. It has been noticed an increasing interest by QOL in the health area, mainly after the changes related to the comprehension of the determining aspects of the health-illness condition, and the establishment and implementation of the principles and targets of Health Promotion. QOL has polysemic notions, in that "it comprehends many different meanings, which reflect the knowledge, experiences, and individuals and collective values of different times, space, and history, being, this way, a social construction with indistinctive cultural aspects"(5).

Health Promotion, as defined in The Ottawa Charter for Health Promotion in 1986, is the "capability process of the community to improve their quality of life and health", and contains a number of factors which promote people's well-being and desirable life conditions, such as food, education, leisure, and work. Consequently, involved professionals should act aiming at humanizing practices and thus assure the individual well-being ${ }^{(6)}$.

In this context, the QOL is understood as a differentiating factor in health assistance leading to the completeness, and development of therapeutic practices ${ }^{(6)}$. Various authors ${ }^{(5-7)}$ discuss the importance in considering QOL under subjective aspects, observing how individuals assess their personal situation, and the different domains the QOL may have, which include social relations, family relations, language, behavior, among other aspects addressed in QOL questionnaires.

Therefore, the QOL is understood as the personal satisfaction in accomplishing their daily activities, personal relation, including romantic, family, and social relations, in living under satisfactory conditions, comprising sanitation, housing, transportation, and food, as well as having access to education, health, and leisure ${ }^{(5-7)}$.

This QOL concept enlarges the numbers of possibilities for health assistance, and consolidates new paradigms of the health-illness process, which favors Health Promotion, and prevents new diseases ${ }^{(5,6)}$.

Several questionnaires were devised to measure the QOL in the health area. In our study, we used a specific questionnaire for cerebrovascular diseases - The Stroke Specific Quality of Life Scale (SS-QOL) ${ }^{(8)}$ - translated and validated to Portuguese ${ }^{(9) *}$. The questionnaires for base population, which do not specify a pathology, are used for epidemiological research and the health system evaluation ${ }^{(5)}$. On the other hand, more specific questionnaires can indicate alterations in the QOL of determined groups of individuals more easily ${ }^{(9)}$, for example, in stroke sequels ${ }^{(7-10)}$. For this reason, in this study we used a specific questionnaire to measure the QOL of stroke patients, mainly the aphasics.

The aphasia, here defined as an alteration in the comprehension and/or language production, is caused by brain damage resulting from, chiefly, a stroke. This condition can result in a negative impact on the person's life, since, besides affecting language, it may interfere in the related processes as practical life, social, affective, interactive, and interpretative relations ${ }^{(1,3,4)}$. Thus, it is of the almost importance to investigate the aspects of aphasics QOL.

Taking into consideration that difficulties in communication are among the aphasic patient's most common complaints, it is important that, during aphasic clinical follow-up procedures, the conditions under which language produced is examined, verbal and non-verbal, analyzing dialogues, and spontaneous narratives, in other words, contextualized actions considering the social subject as an active participant of their own language reconstruction, to increase their $\mathrm{QOL}^{(11-13)}$. Thus, the search of better understanding and the inter-relation of life conditions, one of the factors that interfere in the aphasic subject's language, are of extreme relevance.

In the literature, however, not many studies about aphasics QOL can be found, mainly due to difficulties on the part of the interviewers in dealing with linguistic-cognitive impairments, and also difficulties on the part of the patients in understanding and expressing themselves in a satisfactory way to convey their actual QOL ${ }^{(3,4,14,15)}$. For this reason, some authors ${ }^{(3,14)}$ point out the need to adapt the QOL questionnaires to favor the participation of the aphasics, by, for example, simplifying the questions and using pictures.

In this context, the Augmentative and Alternative Communication (ACC) appears as a possibility to improve aphasics clinical follow-up ${ }^{(11-13,16)}$, mainly in situations in which no advances in clinical therapy are present, or when the advances are poor in order to allow the assessment of the language evolution ${ }^{(17)}$.

The AAC can contribute to benefit the language of people with verbal communication disorder, as it occurs with aphasics, bringing, as a consequence, bad results in their QOL. Thus, the AAC is an important Speech-Language Pathology resource in aphasia ${ }^{(11-13)}$, bearing in mind that "the aphasic patient's quality of life is closely related to the intensity of the aphasia impact upon them" ${ }^{\prime \prime}$. Hence, the AAC is an auxiliary aid to

*The protocol validation in Portuguese did not involve patients with linguistic-cognitive impairment. 
help aphasic subjects to deal with their life conditions, when performing a dialog, as when responding QOL questionnaire.

In view of what has been said here, the purpose of the present study is to investigate and to compare fluent and non-fluent aphasics AAC users.

\section{METHODS}

This is a prospective, quantitative, and transversal study. We included 11 stroke patients with aphasia, participants of the Aphasia Center - Institute of Language Studies, Faculty of Medical Sciences, Universidade Estadual de Campinas.

The sample was composed of individual with ischemic or hemorrhagic stroke diagnosis, and with expressive aphasia. We excluded aphasia patients with important comprehension difficulties, for this would make the application of the QOL questionnaire impossible.

All the Aphasia Center participants are evaluated by the people in charge of this Center, at the time of their entry in the groups, when the aphasia diagnosis is defined, and their participation in the Aphasia Center is determined.

According to the language characteristics, contained in the reports of speech-language therapy, the study participants were divided into two groups: five non-fluent aphasics AAC users - NF group - who also participated in the speech-language therapy with resources of AAC, and six fluent aphasics - F group - non AAC users.

Aphasia has different classifications and, in this research, we do not follow a neuropsychological model, in which reduced verbal expression aphasia and verbal expression fluid aphasia are grouped. According to linguistic criteria, we used the terminology "non-fluent aphasics" to refer to those patients whose language production were fragmented phrases, reduced oral expression, difficulty in producing words, paraphasias, perseverations, verbal stereotypes, prolonged sounds, and other language deficits ${ }^{(18)}$. Fluent aphasics also presented expression aphasia without comprehension difficulties, more fluid oral expression, with ability to form simple and meaningful phases, requiring little help, but with some difficulty in production of words.

The data were gathered in three different ways:

a) application of the Stroke Specific Quality of Life Scale -

SS-QOL, translated and validated to Portuguese ${ }^{(9)}$;

b) structured interview;

c) application of The Modified Rankin Scale ${ }^{(19)}$

This study was approved by the Ethical Committee of the Universidade Estadual de Campinas (UNICAMP) under protocol 124/2008. Informed consent was obtained from every subject or their family.

\section{Stroke Specific Quality of Life Scale (SS-QOL)}

The SS-QOL questionnaire enables the analysis of the QOL of subjects. The SS-QOL comprises 49 items that examine 12 domains, and two parts. The fist part has questions about the individuals' difficulties regarding mobility, upper extremity function, work/productivity, self-care, language, and vision. The second part, with a subscale of 12 areas, evaluates each domain at the present moment compared to the period before the stroke: energy, mood, thinking, personality, social roles, and family roles ${ }^{(8,9)}$.

In each of the 49 items, the subject can get 1 to 5 points or no answer if the question does not apply to their life. The analysis is done by each individual domain. The evaluation of self-care, vision, language, mobility, work/productivity, and upper extremity function domains is done by inquiring about the individual's ability to perform a specific function, and can vary from no help needed/no trouble at all (5) to total help/ could not do it at all (1). The thinking, personality, mood, family roles, social roles, and energy domains refer to the subjects' opinion about a specific situation, and can vary from strongly disagree (5) to strongly agree (1). The quantification of the answers is set by adding up the points 1 to 5 , in which the minimum score is 49 , and the maximum 245 .

For the QOL description, we considered the domains most affected by stroke which had higher frequency of responses 1 (total help/could not do it at all/strongly agree), and 2 (a lot of help/a lot of trouble/moderately agree). We considered the least affected domains which had higher frequency of responses 5 (no help needed/no trouble at all/strongly disagree).

The SS-QOL questionnaire was applied to each subject separately. The questions were read by one of the researchers, and the subjects answered using their communication resources, such as oral communication, AAC symbols, pointing (Figure 1).
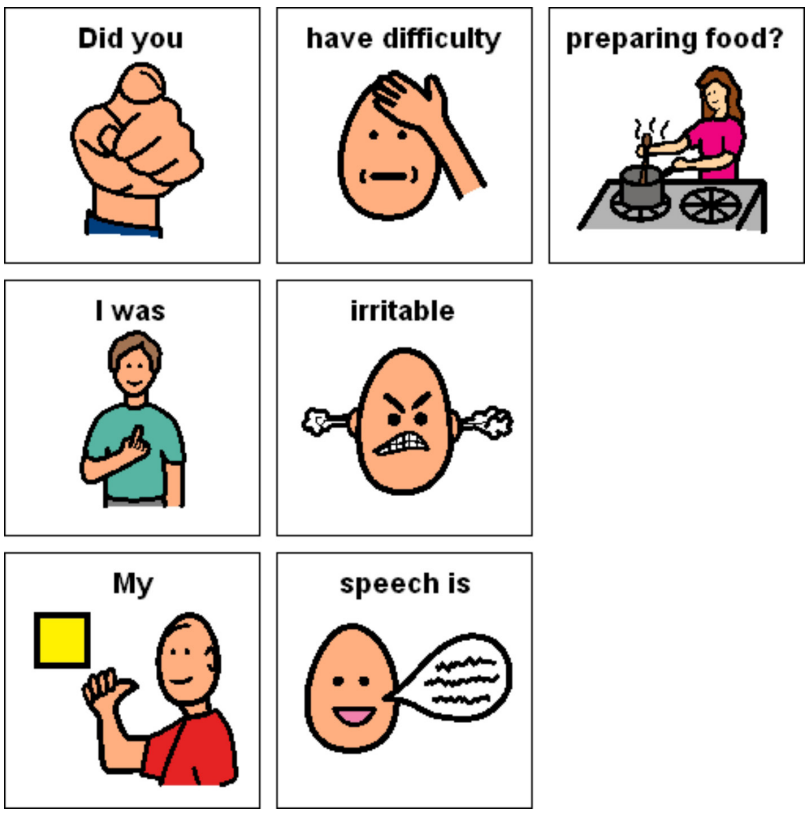

Figure 1. Question examples in the quality of life questionnaire in augmentative and alternative communication 


\section{Structured interview}

The interview aimed to characterize the patients, including socio-demographic factors (age, gender, work, and occupation), clinical history (date and type of stroke), language characteristics (type of aphasia, time participation in the Aphasia Center, AAC use, main communication difficulties, and forms of communication commonly used), and life conditions (need of a caretaker, daily activities).

The interview was conducted with each subject separately and, in some cases, we needed help from the family/caretaker, especially for remembering dates.

\section{The Modified Rankin Scale (mRs)}

This scale assesses the patient's ability to perform daily activities and the dependence when performing tasks, evaluating the overall capacity and the need for assistance after stroke. The scale goes from 0 to 5 , where 0 is perfect health without symptoms, and 5, severe disability.

\section{Statistical analysis}

Statistical and quantitative analyses were carried out with SPSS ${ }^{\circledR} 15.0$ for Windows. Descriptive and dispersion statistics present the characteristics and outcomes of the subjects. The Chi-square test and Mann-Whitney U test were used to compare fluent and non-fluent groups. For the correlation between variables we used the Spearman's Rank-Order Correlation. We considered a p-value lower than 0.05 as statistically significant, and a confidence interval of $95 \%$.

\section{RESULTS}

Regarding the participants characterization, 4 were female, and 7 male, mean age 54 years old $(S D=11)$. In comparing the two groups, NF aphasics and $\mathrm{F}$ aphasics, the main differences were gender ( $\mathrm{p}=0.006)$, and $\mathrm{mRs}(\mathrm{p}=0.0036)$ (Table 1$)$.

The SS-QOL findings showed aspects of the subjects QOL through the description of each of the 12 domains questionnaire. The results for each group are detailed in Figures 2 and 3.

In comparing the two groups, the domains "language" ( $\mathrm{p}=0.009)$ and "upper extremity function" $(\mathrm{p}=0.021)$ were different. The NF group of AAC users showed lower scores (Figure 4).

The most affected domains in the NF group were "language" (64\%), "social roles" (52\%), and "thinking" (46.7\%), whereas in the F group they were "personality" (66\%), "social roles" (50\%), and "thinking" (44.5\%) (Table 2$)$

The least affected domains in the NF group of AAC users were "vision" (86.7\%), "family roles" (66.6\%), and "energy" $(60 \%)$. In the F group, they were "vision" (89\%), "self-care" (87\%), and "mobility" (83\%) (Table 3).

Table 1. General characteristics of the subjects in each group

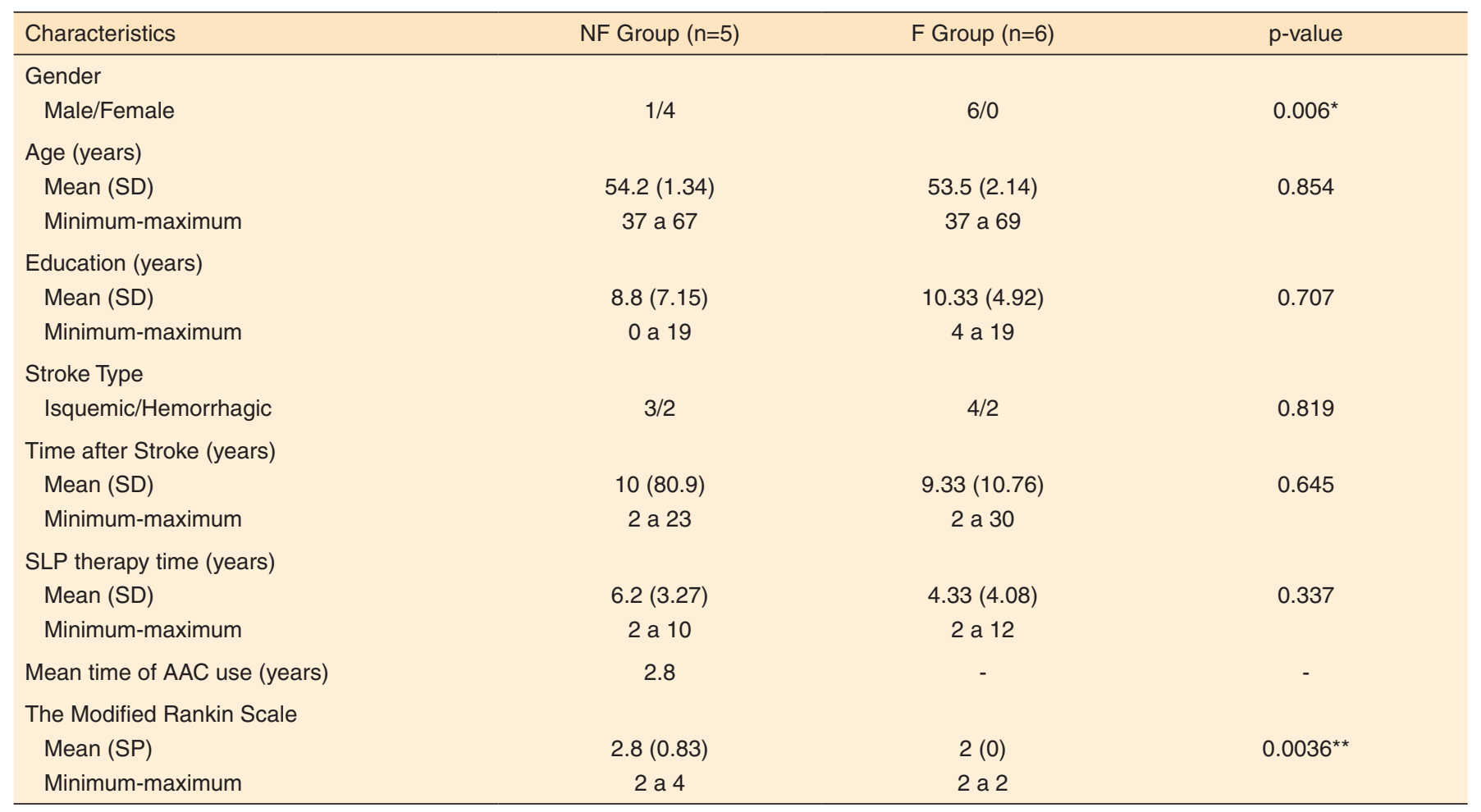

*Significant values $(p<0.05)-$ Chi-squaredTest

${ }^{* *}$ Significant values $(p<0.05)-$ Mann-Whitney U Test

Note: $\mathrm{NF}=$ non-fluent; $\mathrm{F}$ = fluent; $\mathrm{SD}=$ standard deviation; $\mathrm{SLP}=$ Speech-Language Pathology; $\mathrm{AAC}=$ augmentative and alternative communication 


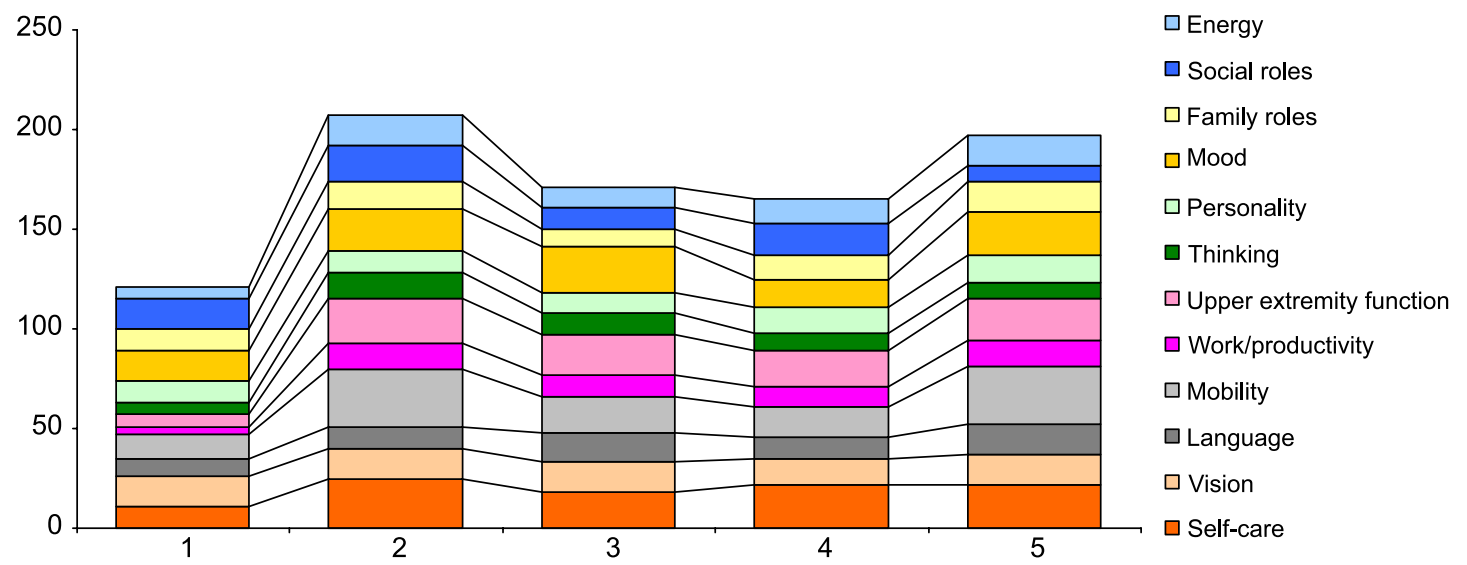

Figure 2. Measures of the quality of life domains in non-fluent group, augmentative and alternative communication users

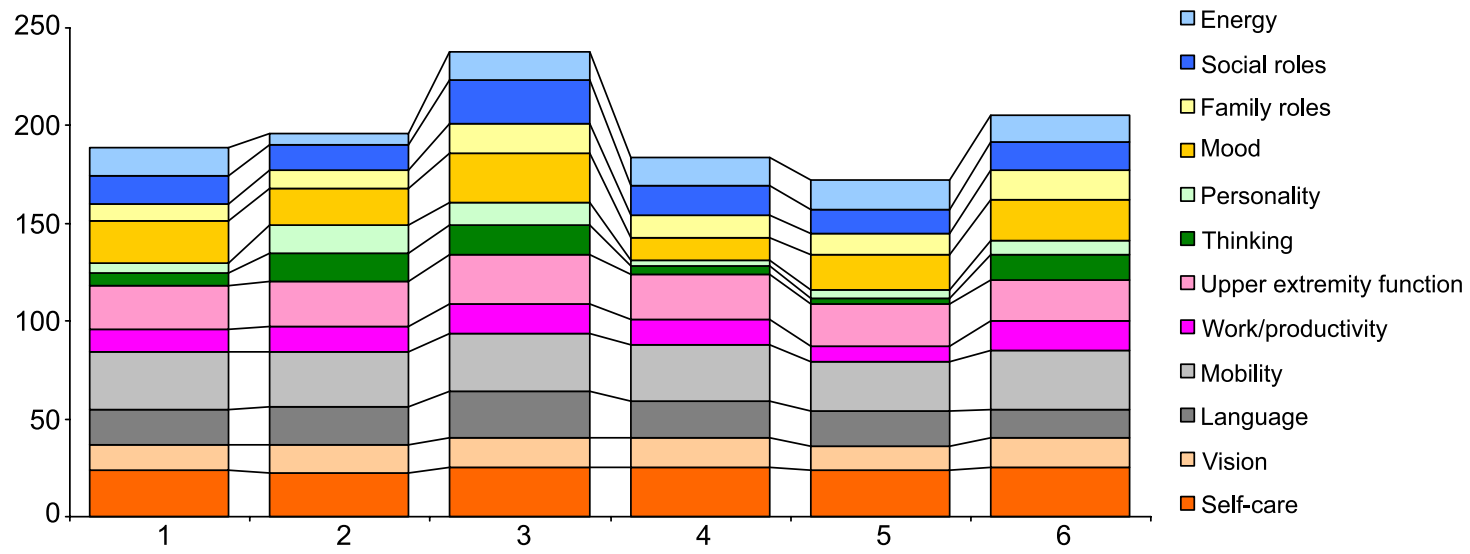

Figure 3. Measures of the quality of life domains in fluent group, non augmentative and alternative communication users

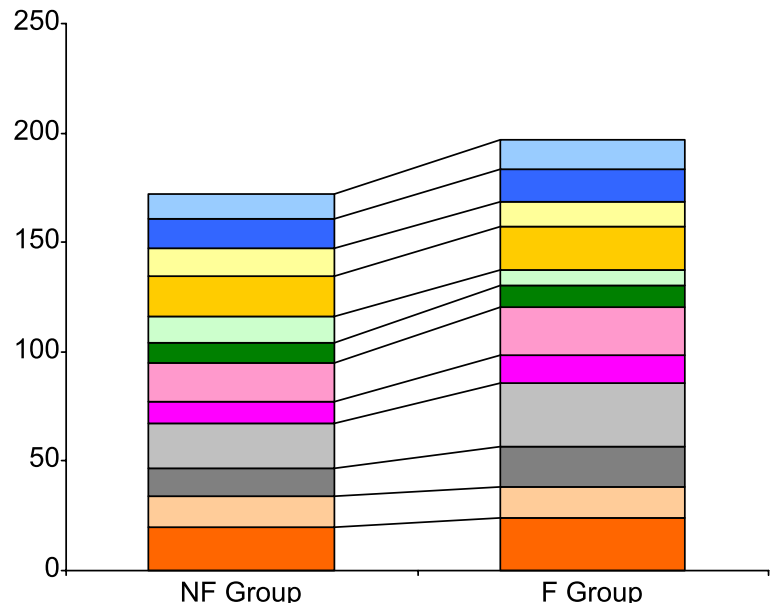

$\square$ Energy
$\square$ Social roles
$\square$ Family roles
$\square$ Mood
$\square$ Personality
$\square$ Thinking
$\square$ Upper extremity function
$\square$ Work/productivity
$\square$ Mobility
$\square$ Language
$\square$ Vision
$\square$ Self-care

Note: $\mathrm{NF}=$ non-fluent; $\mathrm{F}=$ fluent

Figure 4. Measures of the domains of quality of life questionnaire per group

The last part of the questionnaire consists of a subscale with 12 domains previously assessed, comparing the subjects impression of their present moment and the period before the stroke. All subjects in for both groups mentioned that their QOL were worse after the brain damage. Regarding the two groups, the domains "language" $(\mathrm{p}=0.045)$ and "self-care" $(\mathrm{p}=0.011)$ were identified as the most affected after stroke, though the effects were more severe in the NF group.

The correlation between mRs and SS-QOL score was statistically significant $(\mathrm{p}=0.004 ; \mathrm{r}=-0.783)$, indicating that lower individual functionality (i.e. higher $\mathrm{mRs}$ value) is related to lower QOL. 
Table 2. The most affected domains in the quality of life questionnaire, according to higher frequency of answers 1 and 2

\begin{tabular}{lcc}
\hline Domains & NF Group (\%) & F Group (\%) \\
\hline Energy & 20 & 17 \\
Social roles & $52^{*}$ & 50 \\
Family roles & 27 & $33.5^{\star}$ \\
Mood & 24 & 30 \\
Personality & 21 & $66^{*}$ \\
Thinking & $47^{*}$ & $44.5^{\star}$ \\
Upper extremity function & 36 & 7 \\
Work/Productivity & 33 & 11 \\
Mobility & 34 & 3 \\
Language & $64^{*}$ & 7 \\
Vision & 0 & 5.5 \\
Self-care & 24 & 0 \\
\hline
\end{tabular}

${ }^{*}$ The most affected domains

Note: $\mathrm{NF}=$ non-fluent; $\mathrm{F}=$ fluent

Table 3. The least affected domains in the quality of life questionnaire, according to higher frequency of answers 5

\begin{tabular}{lcc}
\hline Domains & NF Group (\%) & F Group (\%) \\
\hline Energy & $60^{*}$ & $78^{*}$ \\
Social roles & 20 & 33 \\
Family roles & $66^{*}$ & 61 \\
Mood & 44 & 64 \\
Personality & 45 & 23 \\
Thinking & 40 & 50 \\
Upper extremity function & 48 & 76 \\
Work/Productivity & 40 & 67 \\
Mobility & 40 & 83 \\
Language & 0 & 23 \\
Vision & $87^{*}$ & $89^{*}$ \\
Self-care & 48 & $87^{*}$ \\
\hline
\end{tabular}

* The least affected domains

Note: $\mathrm{NF}=$ non-fluent; $\mathrm{F}=$ fluent

\section{DISCUSSION}

Studies show that the QOL declines after a stroke, even for individuals with minimal sequel ${ }^{(7,20,21)}$. Among the factors that influence the QOL, we can mention age, low educational level, mobility difficulties, depression, difficulties in social roles, and language changes ${ }^{(22-24)}$.

The sample was mostly formed by adult men, and with independence level varying from little to moderate (mRs). Studies on post-stroke QOL with Brazilian patients show greater incidence for men, with mean age slightly above those of our study, much shorter stroke period, and level of independence compatible with our research ${ }^{(2,9,20,25)}$. In contrast, international studies on post-stroke QOL with aphasics, do not corroborate this difference between genders, presenting higher incidence in women, and mean age 60 and above ${ }^{(23,26)}$.

It is important to consider that there are relevant differences between the study samples, what can explain the results. Our study, for instance, includes few subjects with heterogeneous clinic characteristics.

As for the SS-QOL, though the NF aphasic group presents an average score lower than the value found for the $\mathrm{F}$ aphasic group, indicating lower QOL, there was no significant statistic difference between the groups. Such values are similar to results of other studies with post-stroke Brazilian samples ${ }^{(9,25)}$. However, these studies made use of a population comprising aphasics and non-aphasics.

Research done with another QOL tool comparing fluent and non-fluent aphasics showed that fluent aphasics presented a better QOL score ${ }^{(26)}$. Moreover, the literature in this area reports that the severity of the aphasia is one of the principal predictors to decrease the QOL post-stroke ${ }^{(23,26-28)}$, which agrees with the data found in our study.

Among the SS-QOL domains, language and upper extremity function were statistically different between $\mathrm{F}$ and NF aphasics, with worse rates for the NF aphasics. We did not find comparative studies of these two groups of aphasics using the same QOL questionnaire. Nevertheless, a study with another instrument showed that the domains of communication, physical and psychosocial aspects were different between $\mathrm{F}$ and NF aphasics, and that the NF aphasics showed lower scores in these domains ${ }^{(26)}$.

The current study demonstrated that the domains most affected by stroke were language, social roles, and thinking in the NF aphasics group, and personality, social roles, and thinking in the $F$ aphasics group. These results partly coincide with the findings in Brazilian research. Some authors ${ }^{(2)}$ found that the most affected domains in the SS-QOL are "energy", "work", "upper extremity function", and "social roles". It is worth emphasizing the difference between the sample of our study, using only aphasics, and that of those authors, which use subjects who had a stroke episode but did not present aphasia as a sequel.

An international study shows that the most affected domains by a lesional episode, in aphasic and non-aphasic populations, were upper extremity functional, social roles, and language ${ }^{(10)}$.

The literature shows a close relation between effectiveness of communication, social well-being, and psychological comfort of the aphasic ${ }^{(15,27)}$. It is also clear in the studies that the aphasic has a higher number of depression symptoms, difficulties in performing daily activities, and higher level of dependence ${ }^{(15,20,27,29,30)}$. Moreover, the aphasic's condition limits social relations ${ }^{(7,27)}$, which explains the findings.

Our study found that the least affected domains in the NF aphasic group are "vision", "family roles", and "energy", and in the F aphasic group, the domains of "vision", "self-care", and "mobility". A Brazilian study indicated "vision", "mood", "personality", and "family roles" as the least affected domains in the SS-QOL ${ }^{(2)}$.

In the final subscale of the questionnaire, the subjects compare each domains in the present days and before the stroke, and they all evaluate that their QOL worsened after the lesional 
episode. However, other studies ${ }^{(9,28)}$ show that part of the subjects indicate their QOL remained the same after the stroke. This difference can be explained by the reduced size of the sample in our study, and also, because it refers to a population of aphasics only.

In the comparison between $\mathrm{NF}$ and $\mathrm{F}$ aphasics, the domains "language" and "self-care" present significant difference, with the worst domains belonging to the NF aphasics. Such findings coincide with the literature already mentioned, in which the aspects related to both communication and physical aspects were also different between $\mathrm{F}$ and $\mathrm{NF}$ aphasics ${ }^{(26)}$.

There was a correlation between the mRs and the total score of SS-QOL, indicating that the functioning of the individuals is related to the QOL. Another study points out this correlation by showing that people who have worse functioning conditions have lower $\mathrm{QOL}^{(20)}$. It also shows that individuals with better level of functioning and communication condition have less social restrictions, higher QOL, and better emotional health ${ }^{(27)}$, which agrees with the general findings of our study.

The literature in the area mentions the role of AAC as a facilitator of the oral and discursive production in NF aphasics, promoting changes in this group social relations ${ }^{(11-13)}$. Thus, we can infer that the AAC contributes to positive changes in the QOL of the aphasic.

\section{CONCLUSION}

Our study shows the differences and the impact of aphasia in the QOL of the groups studied, indicating that non-fluent aphasics, with greater difficulty in communication, have lower QOL. Additionally, there is a relation between language, psychosocial factors, and the functioning of individuals, as evidenced in the SS-QOL domains.

These findings expose important aspects to be considered in the intervention in the aphasic health, focusing on the needs of each individual, as well as being an important tool to measure and understand the impact of the disease on the aphasic's life. Also, the results indicate the AAC resources as a possibility of greater participation of the aphasic in communicative situations, being an auxiliary language resource, and able to favor changes in the QOL of this population.

The AAC is suggested as an issue for future research in the area, in order to benefit health assistance in a humanized way, as a comprehensive health care, to promote health while improving physical and psychosocial well-being, and to change fluent and non-fluent aphasic's lives for the better.

\section{REFERENCES}

1. Universidade Estadual de Campinas, Instituto da Linguagem. Sobre as afasias e os afásicos: subsídios teóricos e práticos elaborados pelo Centro de Convivência de Afásicos (Universidade Estadual de Campinas). Campinas: Editora Unicamp; 2002.
2. Cordini LK, Oda EY, Furlanetto LM. Qualidade de vida de pacientes com história prévia de acidente vascular encefálico: observação de casos. J Bras Psiquiatr. 2005;54(4):312-17.

3. Worrall L, Holland A. Quality of life in aphasia. Aphasiology. 2003;17(4):329-32.

4. Hilari K, Byng S. Health-related quality of life in people with severe aphasia. Int J Lang Comm Dis. 2009;44(2):193-205. http://dx.doi. org/10.1080/13682820802008820

5. Minayo MCS, Hartz ZMA, Buss PM. Qualidade de vida e saúde: um debate necessário. Ciênc Saúde Coletiva. 2000;5(1):7-18. http://dx.doi. org/10.1590/S1413-81232000000100002

6. Seidt EMF, Zannon CMLC. Qualidade de vida e saúde: aspectos conceituais e metodológicos. Cad Saúde Pública. 2004; 20(2):580-8. http://dx.doi.org/10.1590/S0102-311X2004000200027

7. Carod-Artal FJ. Determining quality of life in stroke survivors. Expert Rev Pharmacoecon Outcomes Res. 2012;12(2):199-211. http:// dx.doi.org/10.1586/erp.11.104

8. Williams LS, Wienberger M, Harris LE, Clark DO, Biller J. Development of a stroke-specific quality of life scale. Stroke. 1999;30(7):1362-69. http://dx.doi.org/10.1161/01.STR.30.7.1362

9. Santos AS. Validação da escala de avaliação da qualidade de vida na doença cerebrovascular isquêmica para a língua portuguesa [doctor's thesis]. São Paulo: Faculdade de Medicina da Universidade de São Paulo; 2007.

10. Williams LS, Wienberger M, Harris LE, Biller J. Measuring quality of life in a way that is meaningful to stroke patients. Neurology. 1999;53(8):1838-43.

11. Galli JFM, Oliveira JP, Deliberato D. Introdução da comunicação suplementar e alternativa na terapia com afásicos. Rev Soc Bras Fonoaudiol. 2009;14(3):402-10. http://dx.doi.org/10.1590/S151680342009000300018

12. Chun RYS. Processos de significação de afásicos usuários de comunicação sumplementar e/ou alternativa. Rev Soc Bras Fonoaudiol. 2010;15(4):598-603. http://dx.doi.org/10.1590/S151680342010000400021

13. Bahia MM, Chun RYS. Augmentative and alternative communication repercussion on non-fluent aphasia. Rev CEFAC. 2014;16(1):147-60. http://dx.doi.org/10.1590/1982-021620146612

14. Hilari K e Byng S. Measuring quality of life in people with aphasia: the Stroke Specific Quality of Life Scale. Int J Lang Commun Disord. 2001;36 suppl 1:86-91. http://dx.doi.org/10.3109/13682820109177864

15. Cruice M, Worrall L. Hickson L. Health-related quality of life in people with aphasia: implications for fluency disorders quality of life research. J Fluency Disord. 2010;35(3):173-89. http://dx.doi. org/10.1016/j.jfludis.2010.05.008

16. Johnson RK, Hough MS, King KA, Vos P, Jeffs T. Functional communication in individuals with chronic severe aphasia using augmentative communication. Augment Altern Commun. 2008;24(4):269-80. http://dx.doi.org/10.1080/07434610802463957

17. Couto EAB. Utilização dos sistemas aumentativos e alternativos de comunicação na reabilitação das afasias. In: Almirall CB, Soro-Camats E, Bultó CR. Sistemas de sinais e ajudas técnicas para a comunicação alternativa e a escrita. São Paulo: Santos; 2003. p. 231-41. 
18. Fedosse E. Acompanhamento fonoaudiológico de um sujeito afásico não-fluente: continuidade sonsório-motora. Distúrb Comun. 2007;19(3):403-14.

19. Bonita R, Beaglehole R. Recovery of motor function after stroke. Stroke. 1988;19(12):1497-500. http://dx.doi.org/10.1161/01. STR.19.12.1497

20. Carod-Artal FJ, Trizotto DS, Coral LF, Moreira CM. Determinants of quality of life in Brazilian stroke survivors. J Neurol Sci. 2009;284(12):63-8. http://dx.doi.org/10.1016/j.jns.2009.04.008

21. Kauhanen ML, Korpelainen JT, Hiltunen P, Nieminen P, Sotaniemi KA, Myllylä VV. Domains and determinants of quality of life after stroke caused by brain infarction. Arch Phys Med Rehabil. 2000;81(12):1541-6. 22. Paul SL, Sturm JW, Dewey HM, Donnan GA, Macdonell RAL, Thrift AG. Long-term outcome in the North East Melbourne Stroke Incidence study: predictors of quality of life at 5 years after stroke. Stroke. 2005;36(10):2082-6. http://dx.doi.org/10.1161/01. STR.0000183621.32045.31

23. Hilari K, Wiggins R, Roy P, Byng S, Smith S. Predictors of health-related quality of life (HRQOL) in people with chronic aphasia. Aphasiology. 2003;17(4):365-81. http://dx.doi. org/10.1080/02687030244000725

24. Singpoo K, Charerntanyarak L, Ngamroop R, Hadee N, Chantachume
W, Lekbunyasin $\mathrm{O}$ et al. Factors related to quality of life of stroke survivors. J Stroke Cerebrovasc Dis. 2012;21(8):776-81. http://dx.doi. org/10.1016/j.jstrokecerebrovasdis.2011.04.005

25. Tubone MQ. Avaliação da qualidade de vida em pacientes portadores de doença cerebrovascular do tipo isquêmico [course conclusion]. Santa Catarina: Universidade Federal de Santa Catarina; 2007.

26. Posteraro L, Formis A, Grassi E, Bighi M, Nati P, Proietti Bocchini $\mathrm{C}$ et al. Quality of life and aphasia: multicentric standardization of a questionnaire. Eura Medicophys. 2006;42(3):227-30.

27. Cruice M, Worrall L, Murison R, Hickson L. Finding a focus for quality of life with aphasia: social and emotional health, a psychocological well-being. Aphasiology. 2003;17(4):333-53. http:// dx.doi.org/10.1080/02687030244000707

28. Patel MD, McKevitt C, Lawrence E, Rudd AG, Wolfe CDA. Clinical determinants of long-term quality of life after stroke. Age Aging. 2007;36(3):316-22. http://dx.doi.org/10.1093/ageing/afm014

29. Hilari K. The impact of stroke: are people with aphasia different to those without? Disabil Rehabil. 2011;33(3):211-8. http://dx.doi.org/10.3 109/09638288.2010.508829

30. Ross K, Wertz R. Quality of life with and without aphasia. Aphasiology. 2003;17(4):355-64. http://dx.doi. org/10.1080/02687030244000716 